ГАЛУЗЕВИЙ АСПЕКТ РОЗВИТКУ НАЦІОНАЛЬНОГО ГОСПОДАРСТВА

УДК 336.648

DOI: 10.25140/2411-5215-2021-1(25)-15-26

Інна Хоменко, Людмила Волинеиь, Антон Шамкало

\title{
ОСОБЛИВОСТІ НАДХОДЖЕННЯ ПРЯМИХ ІНОЗЕМНИХ ІНВЕСТИЦІЙ ТА ЇХНІЙ ВПЛИВ НА ЕКОНОМІКУ УКРАЇНИ
}

\author{
Inna Khomenko, Lyudmila Volynets, Anton Shamkalo \\ FEATURES OF THE INFLOW OF FOREIGN DIRECT INVESTMENT \\ AND THEIR IMPACT ON THE ECONOMY OF UKRAINE
}

У статті визначено особливості інвестиційної діяльності та необхідність залучення суб'єктами господарювання іноземних інвестииій. Проаналізовано тендениії надходження прямих іноземних інвестицій (ПІІ) в Україну. 3'ясовано, які галузі та чому залучають найбільше іноземних інвестицій та з огляду на незбалансованість структури інвестицій, визначено питому вагу изих галузей у загальній структурі економіки. Проведено аналіз діяльності українських стартапів, щу залучили найбільще ПІІ в 2020 рочџ та спрогнозовано майбутній розвиток компаній. Проаналізовано положення України серед країн світу за легкістю ведення бізнесу та визначити перешкоди, що стають на заваді підняттяя в рейтингу «DOING BUSINESS».

Очінено передумови створення вільних економічних зон. Розкрито поняття «офиор» та визначено яким чином в Україні проводиться політика проти «відмиванням коштів». Визначено негативні фактори, які є чинниками погірмення інвестиційного клімату та в довгостроковій перспективі є перешкодами до зростання обсягів інвестування. Запропоновано та обтрунтовано потенційні шляхи покращчення інвестиційного клімату Украйни на основі світового досвіду.

Ключові слова: прямі іноземні інвестицї; інвестичійна діяльність; проєкт; стартап; вільна економічна зона; офиор.

Рис.: 5. Табл.: 2. Бібл.: 21.

This article identifies the features of investment activities and the need to attract foreign investment by business entities. Trends in foreign direct investment (FDI) inflows to Ukraine are analyzed. It was found out which industries attract the most foreign investment and why, and given the imbalance in the structure of investment, the share of these industries in the overall structure of the economy was determined. An analysis of the activities of Ukrainian startups that attracted the most FDI in 2020 and predicts the future development of companies. The position of Ukraine among the countries of the world in terms of ease of doing business is analyzed and to identify "obstacles" that hinder the rise in the rating "DOING BUSINESS".

The preconditions for the creation of free economic zones are assessed. The concept of "offshore" is revealed and it is determined how the policy against "money laundering" is conducted in Ukraine. Negative factors have been identified, which are factors in the deterioration of the investment climate and in the long run are obstacles to the growth of investment. Potential ways to improve Ukraine's investment climate based on world experience are proposed and substantiated.

Keywords: foreign direct investment; investment activity; project; startup; free economic zone; offshore.

Fig.: 5. Table: 2. References: 21.

JEL Classification: F21; O52

Постановка проблеми. Нині Україну можна вважати однією із країн, що активно інтегруються в європейський простір, але мають низький рівень життя відносно Свропи. Економічний спад, нестача робочих місць, низька заробітна плата і пенсійне забезпечення, при високих тарифах на комунальні послуги та ціни в супермаркетах. Криза, викликана пандемією COVID-19, фактично не внесла в економіку нашої країни жодних корективів, а лише змусила і без того ряд значущих проблем нагадати про себе. Зростання виробництва та доданої вартості й відповідно нарощення валового внутрішнього продукту України за допомогою надходження прямих іноземних інвестицій (ПII) в значному обсязі може бути шляхом вирішення всієї низки проблем.

Аналіз останніх досліджень та публікацій. Процеси прямого іноземного інвестування на сучасному етапі досліджували такі закордонні та вітчизняні науковці, як Л. Гітман, В. Геєць, Б. Карпінський, Н. Татаренко, А. Поручник, Дж. Кейнс, Л. Катан, В. Федоренко, У. Шарп, І. Бланк, І. Несходовський, Л. Тимошенко, Н. Масі, Г. Цукман та інші.

На основі вивчення наукових робіт вітчизняних та закордонних учених (табл. 1), можна зробити висновок, що інвестування передбачає собою вкладення власних коштів 3 метою їх подальшої капіталізації (збільшення їх обсягу) [1].

(C) Хоменко I. О., Волинець Л. М., Шамкало А. О., 2021 
Таблиця 1

Трактування економічної категорії «інвестиційна діяльність»

\begin{tabular}{|l|l|}
\hline \multicolumn{1}{|c|}{ Науковці } & \multicolumn{1}{c|}{ Визначення } \\
\hline $\begin{array}{l}\text { Н. О. Татаренко, } \\
\text { А. М. Поручник }\end{array}$ & $\begin{array}{l}\text { послідовна, цілеспрямована діяльність, що полягає в капіталізації об’єктів } \\
\text { власності, у формуванні та використанні інвестиційних ресурсів, регулю- } \\
\text { ванні процесів інвестування і міжнародного руху інвестицій та інвестицій- } \\
\text { них товарів, створенні відповідного інвестиційного клімату і має на меті } \\
\text { отримання прибутку або певного соціального ефекту }\end{array}$ \\
\hline $\begin{array}{l}\text { В. М. Геєць, } \\
\text { В. Г. Федоренко, } \\
\text { Б. А. Карпінський }\end{array}$ & $\begin{array}{l}\text { як процес вкладення інвестицій (інвестування), а також сукупність практи- } \\
\text { чних дій із реалізації інвестицій }\end{array}$ \\
\hline Л. М. Тимошенко & $\begin{array}{l}\text { вкладення інвестицій (інвестування) і сукупність практичних дій щодо їх- } \\
\text { ньої реалізації }\end{array}$ \\
\hline П. Масі & $\begin{array}{l}\text { як акт вкладення капіталу, що полягає в обміні задоволення сьогоднішньої } \\
\text { потреби на очікування ії в майбутньому за допомогою інвестованих благ }\end{array}$ \\
\hline
\end{tabular}

Виділення недосліджених частин загальної проблеми. Попри постійні спроби Уряду протистояти легалізації доходів злочинним шляхом, майже 80 \% українських компаній ухиляються від подання даних про кінцевих бенефіціарних власників. Як наслідок, можемо спостерігати відсутність контролю Round tripping (кругових) інвестицій, частка яких становить 34,1 \% загального обсягу ПІІ. У зв'язку із застоєм розвитку виробництва, економічне зростання України є значно сповільненим у порівнянні з іншими країнами Свропи. Відсутні ефективні управлінські рішення з боку Міністерства розвитку економіки, торгівлі та сільського господарства України, які б сприяли постіндустріалізації та створенні привабливого інвестиційного клімату. Основними причинами незадовільного стану інвестиційної діяльності в Україні є відсутність ефективної інвестиційної політики та ії непослідовний і часто суперечливий характер. Крім того, питання, що стосуються інвестування, особливо в сучасних умовах не достатньо вивчені.

Мета дослідження. Метою цієї статті є дослідження тенденцій здійснення іноземними фізичними та юридичними особами інвестиційної діяльності на території України, а також визначення чинників, які є ключовими для покращення інвестиційного клімату та нарощення ВВП за рахунок залучення прямих іноземних інвестицій.

Виклад основного матеріалу. У цій статті використано такі методи, як метод кількісного та якісного порівнянь (під час оцінювання стану інвестиційного клімату України за рахунок аналізу рейтингу країн за легкістю ведення бізнесу), синтез та аналіз (у процесі розгляду діяльності найуспішніших українських новітніх проєктів (стартапів)), системно-структурний аналіз економічних процесів і явищ (для дослідження надходження ПІІ в Україну), метод моделювання (для обгрунтування запропонованих шляхів покращення інвестиційного клімату з урахуванням світового досвіду).

Результати дослідження та обговорення. У ролі інвесторів переважно виступають фізичні та юридичні особи інших держав, оскільки в інвестиційні проєкти вкладають саме «вільні» гроші (якими, на жаль, резиденти України володіють у досить рідких випадках). Аналіз тенденції надходження прямих іноземних інвестицій показує, що економіка України нарощувала запаси ПІІ до кризи 2008 року, після подальшого розвитку спостерігається стрімке падіння наприкінці 2013 - початку 2014 років у зв'язку з державним переворотом. Надалі іноземні інвестори починають поступово вкладати кошти в українськи проєкти, але в значно меншому обсязі, якщо порівнювати з минулими роками. Потім вже за 2020 року ми знову можемо спостерігати сповільнене надходження та відтік інвестицій, що, на думку науковців та експертів, спричинено всесвітньою кризою через COVID-19 [2]. 
ГАЛУЗЕВИЙ АСПЕКТ РОЗВИТКУ НАЦІОНАЛЬНОГО ГОСПОДАРСТВА

Зважаючи на статистичні дані, можемо спостерігати особливо різкий відтік прямих іноземних інвестицій в 2014 році, що пов'язано насамперед з дестабілізацією ситуації на Сході нашої країни. Не варто забувати, що дані, починаючи з того ж року, взяті без урахування окупованих територій (Криму, Севастополя, частини Луганської та Донецької областей). Проте, на думку експертів, збройний конфлікт не є головним чинником того, надходять інвестиції чи ні. Можна розглянути досвід такої відомої країнипартнера, як Ізраїль. Ця країна протягом багатьох десятиліть розвивається у стані війни, і тенденцію щодо вирішення конфлікту в найближчі роки ми поки що не спостерігаємо. Тим не менш, Ізраїль має активи, які приваблюють іноземних інвесторів: потужний сектор дослідження і розробок, а також висококваліфікована і багатомовна робоча сила. Сектор високих технологій, особливо стартапи, залучив багато іноземних інвестицій. Безумовно, не лише інновації є основою залучення інвесторів. $C$ значна кількість чинників, які стримують інвестування та потребують негайному вирішенню.

Проаналізувавши положення України на світовому ринку за легкістю ведення бізнесу, можна виділити те, що є ключові фактори, які «тягнуть на дно» нашу державу як інвестиційно привабливу. Зокрема, підключення до електромережі є досить складним та недешевим процесом для потенційного інвестора. Незважаючи на відносно прозорі тарифи (за оцінкою doingbusiness. org - 7/8), термін повного підключення понад 260 днів, а вартість у відсотках від доходу населення становить близько 350 \% (дані на 2020 р.). Враховуючи підвищення цін на електроенергію з 1 січня 2021 року, важко уявити негативні наслідки для інвестиційного клімату України. Процедура складається з п’яти етапів, які мають бути переглянутими та переоціненими експертами з метою скорочення терміну підключення об'єктів до електромережі. Кожен інвестор зацікавлений в якнайскорішому поверненні залучених коштів та отриманні прибутку. Але якщо лише електроенергія на підприємстві з'явиться через тривалий термін, то випуск продукції або надання послуг вкладник побачить зовсім не скоро, не кажучи вже про прибуток [3].

Згідно з даними Національного банку України можна зробити припущення, що фактична сума ПІІ значно менша від офіційної статистики, оскільки чимала частка припадає на країни з так званим сприятливим податковим кліматом та навіть на офіційні офшорні зони. Тобто фактично відбувається залучення коштів резидента України до фінансового центру (офшору), звідки потім гроші потрапляють в українські компанії під виглядом інвестицій [4].

Найбільш інвестиційно привабливими галузями на сьогодні можна вважати переважно ті, де максимально швидко виробляється нова продукція з постійно змінною номенклатурою та асортиментом. До таких галузей належать сфера оптової та роздрібної торгівлі, а також переробна промисловість. На думку вчених з центру Разумкова, основним фактором привабливості цих галузей є низькі комерційні ризики. Потоки ПІІ по регіонам у 2017-2019 рр. наведено в табл. 2 і рис. 1 [5].

Таблиця 2

Потоки ПІІ по регіонам у 2017-2019 рр.(млрд. дол.) [6].

\begin{tabular}{|l|c|c|c|c|c|c|}
\hline \multirow{2}{*}{ Регіон } & \multicolumn{3}{c|}{ Ввіз ПІІ } & \multicolumn{3}{c|}{ Вивіз ПІІ } \\
\cline { 2 - 8 } & $\mathbf{2 0 1 7}$ & $\mathbf{2 0 1 8}$ & $\mathbf{2 0 1 9}$ & $\mathbf{2 0 1 7}$ & $\mathbf{2 0 1 8}$ & $\mathbf{2 0 1 9}$ \\
\hline Весь світ & 2 & 3 & 4 & 5 & 6 & 7 \\
\hline Розвинуті країни & 1700 & 1495 & 1540 & 1601 & 986 & 1314 \\
\hline Свропа & 950 & 761 & 800 & 1095 & 534 & 917 \\
\hline Північна Америка & 570 & 364 & 429 & 539 & 419 & 475 \\
\hline Країни, що розвиваються & 304 & 297 & 297 & 379 & -41 & 202 \\
\hline Африка & 701 & 699 & 685 & 467 & 415 & 373 \\
\hline Азія & 42 & 51 & 45 & 12 & 8 & 5 \\
\hline
\end{tabular}


Закінчення табл. 2

\begin{tabular}{|l|c|c|c|c|c|c|}
\hline \multicolumn{1}{|c|}{1} & 2 & 3 & 4 & 5 & 6 & 7 \\
\hline Східна та Південно-східна Азія & 422 & 416 & 389 & 367 & 345 & 280 \\
\hline Східна Азія & 52 & 52 & 57 & 11 & 12 & 12 \\
\hline Західна Азія & 28 & 30 & 28 & 39 & 50 & 36 \\
\hline Латинська Америка та Карибський басейн & 156 & 149 & 164 & 38 & 0,1 & 42 \\
\hline Океанія & 1 & 1 & 1 & 0,1 & $-0,3$ & -1 \\
\hline Країни з перехідною економікою̈ & 50 & 35 & 55 & 38 & 38 & 24 \\
\hline $\begin{array}{l}\text { Країни зі структурою слабкої, чутливої і ма- } \\
\text { лої економіки }\end{array}$ & $\mathbf{4 0}$ & $\mathbf{3 9}$ & $\mathbf{3 9}$ & $\mathbf{6}$ & $\mathbf{2}$ & $\mathbf{0 , 4}$ \\
\hline Найменш розвинуті країни & 21 & 22 & 21 & 2 & 1 & -1 \\
\hline $\begin{array}{l}\text { Країни, що розвиваються, які не мають виходу } \\
\text { до моря }\end{array}$ & 26 & 22 & 22 & 4 & 1 & 0,5 \\
\hline Малі острівні держави, що розвиваються & 4 & 4 & 4 & 0,3 & 0,3 & 1 \\
\hline \multicolumn{1}{|c|}{ Частка в імпорті світових ПІІ, \% } & \multicolumn{3}{|c|}{} \\
\hline Розвинуті країни & 55,9 & 50,9 & 52 & 68,4 & 54,1 & 69,8 \\
\hline Свропа & 33,5 & 24,3 & 27,9 & 33,7 & 42,5 & 36,1 \\
\hline Північна Америка & 17,9 & 19,9 & 19,3 & 23,7 & $-4,1$ & 15,3 \\
\hline Країни що розвиваються & 41,2 & 46,8 & 44,5 & 29,2 & 42 & 28,4 \\
\hline Африка & 2,4 & 3,4 & 2,9 & 0,8 & 0,8 & 0,4 \\
\hline Азія & 29,5 & 33,4 & 30,8 & 26 & 41,2 & 24,9 \\
\hline Східна та Південно-східна Азія & 24,8 & 27,8 & 25,2 & 22,9 & 34,9 & 21,3 \\
\hline Східна Азія & 3 & 3,5 & 3,7 & 0,7 & 1,2 & 0,9 \\
\hline Західна Азія & 1,6 & 2,0 & 1,8 & 2,4 & 5,1 & 2,7 \\
\hline Латинська Америка та Карибський басейн & 9,2 & 10 & 10,7 & 2,4 & 0,01 & 3,3 \\
\hline Океанія & 0,1 & 0,1 & 0,1 & 0,01 & $-0,03$ & $-0,1$ \\
\hline Країни з перехідною економікою & 2,9 & 2,3 & 3,6 & 2,4 & 3,8 & 1,8 \\
\hline $\begin{array}{l}\text { Країни зі структурою слабкої, чутливої і ма- } \\
\text { лої економіки }\end{array}$ & $\mathbf{2 , 4}$ & $\mathbf{2 , 6}$ & $\mathbf{2 , 5}$ & $\mathbf{0 , 4}$ & $\mathbf{0 , 2}$ & $\mathbf{0 , 0 3}$ \\
\hline Найменш розвинуті країни & 1,2 & 1,5 & 1,4 & 0,1 & 0,1 & 0,04 \\
\hline $\begin{array}{l}\text { Країни, що розвиваються, які не мають виходу } \\
\text { до моря }\end{array}$ & 1,5 & 1,5 & 1,4 & 0,2 & 0,1 & 0,04 \\
\hline Малі острівні держави, що розвиваються & 0,2 & 0,2 & 0,3 & 0,02 & 0,04 & 0,1 \\
\hline
\end{tabular}

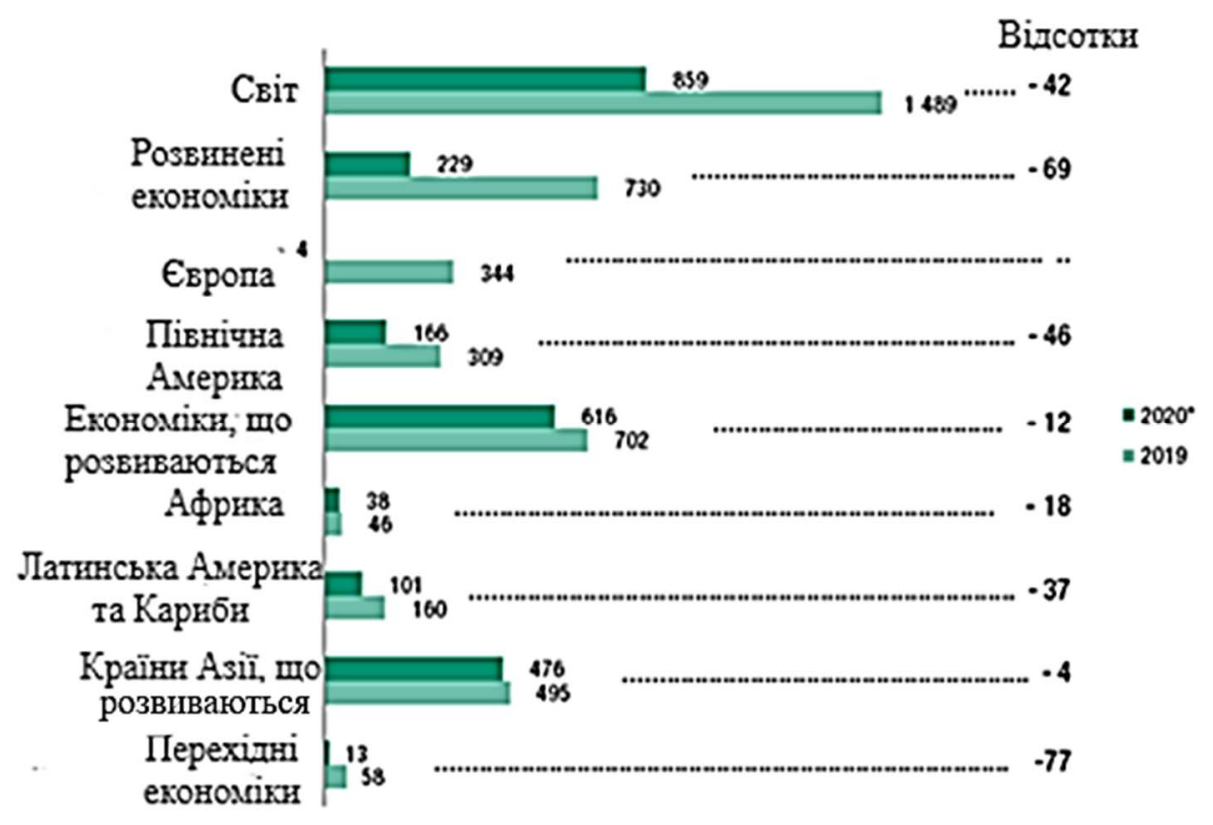

Рис. 1. Надходження ПІІ по регіонам, 2019-2020 рр.

Джерело: UNCTAD (preliminary estimates) [6]. 
ГАЛУЗЕВИЙ АСПЕКТ РОЗВИТКУ НАЦІОНАЛЬНОГО ГОСПОДАРСТВА

Якщо аналізувати рух прямих іноземних інвестицій світу, то можемо спостерігати, що світові ПІІ впали в 2020 році, скоротившись на $42 \%$ з 1,5 трлн дол. у 2019 р. до 859 млрд дол., згідно з моніторингом інвестиційних тенденцій. Такий низький рівень спостерігався в 1990-х роках і більше ніж на 30 \% нижче інвестиційного мінімуму, що був після глобальної фінансової кризи 2008-2009 рр. Приплив прямих іноземних інвестицій у глобальному масштабі по групах країн у 2007-2020 pр. (млрд дол. США) наведено на рис. $2[6 ; 17]$.
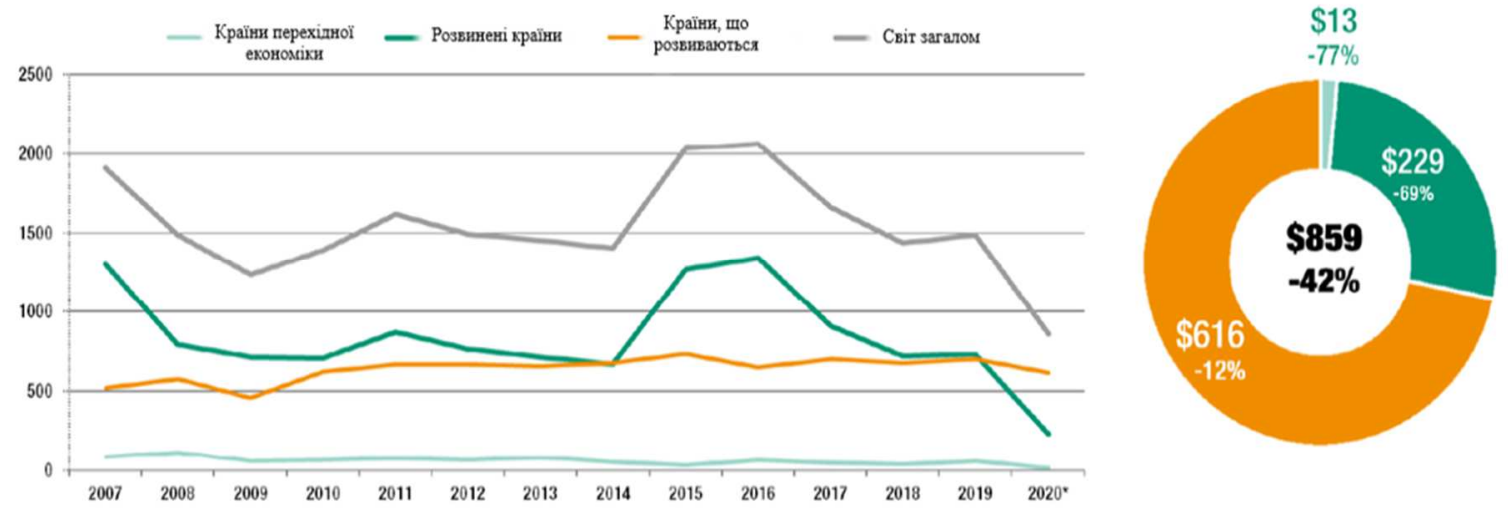

Рис. 2. Надходження прямих іноземних інвестицій в глобальному масштабі по групах краӥн, 2007-2020 роки.

Джерело: UNCTAD (preliminary estimates) [6].

Світова пандемія COVID-19 негативно вплинула на ПII. У 2020 р. відбулося значне зниження глобального припливу ПІІ до 40 \%, проти 2019 р. у 1,54 трлн дол. У 2021 р. за прогнозами аналітиків спостерігається зменшення ще на 5-10\%. Цей прогноз пов'язаний зі значним впливом світової кризи на економіку країн світу, вчасністю дій влади по усуненню негативних наслідків COVID-19, фінансовими ризиками. Прогнозоване падіння значно перевищує спад після глобальної фінансової кризи. На найнижчому рівні (1,2 трлн дол.) у 2009 році глобальний приплив ПІІ був приблизно на 300 млрд. дол. вище, ніж у нижній частині прогнозу 2020 року (рис. 3) [18].
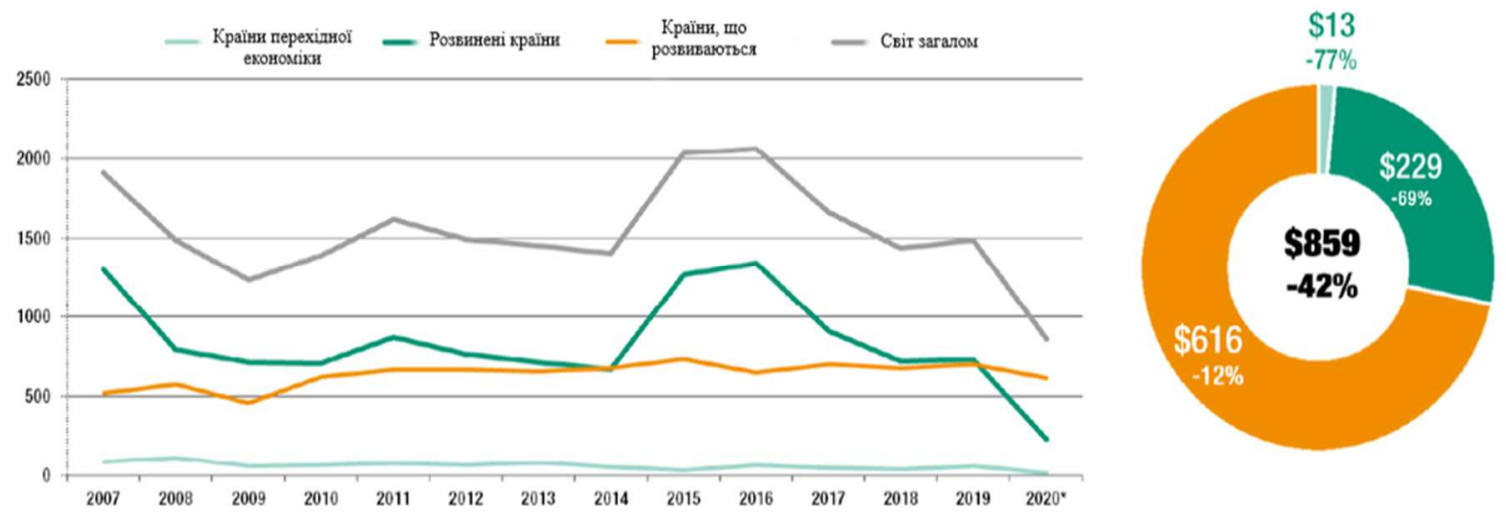

Рис. 3. Прогноз глобального припливу ПІІ на 2015-2019 і 2020-2022 роки Джерело: UNCTAD [6].

Впив короткострокових, середньострокових і довгострокових наслідків пандемії на економіку країн світу (рис. 4.) [18]. 
ГАЛУЗЕВИЙ АСПЕКТ РОЗВИТКУ НАЦІОНАЛЬНОГО ГОСПОДАРСТВА

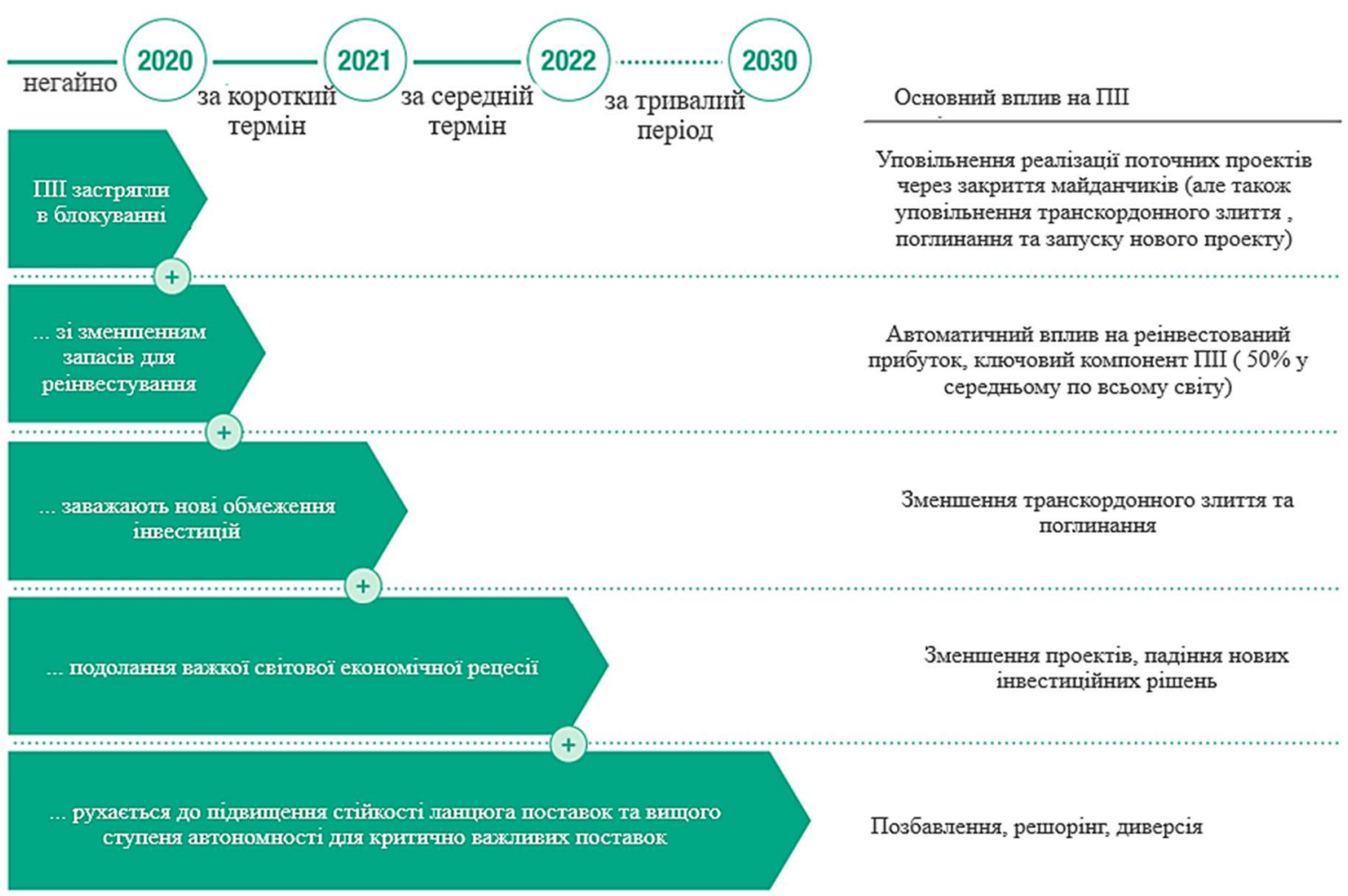

Джерело: UNCTAD [6].

Рис. 4. Вплив пандемії на ПІІ

Щодо вартості й кількості оголошених проєктів ПІІ у сфері «зелених» інвестицій по секторах і окремих галузях (2010-2019 рр.), то загальна вартість проєктів впала на 14 \% (846 млрд дол.) через зниження середнього розміру проєкту. Інвестиційна активність зменшилась на $1 \%$. Крім того, можемо спостерігати загальне зниження їх кількості (рис. 5) [7].
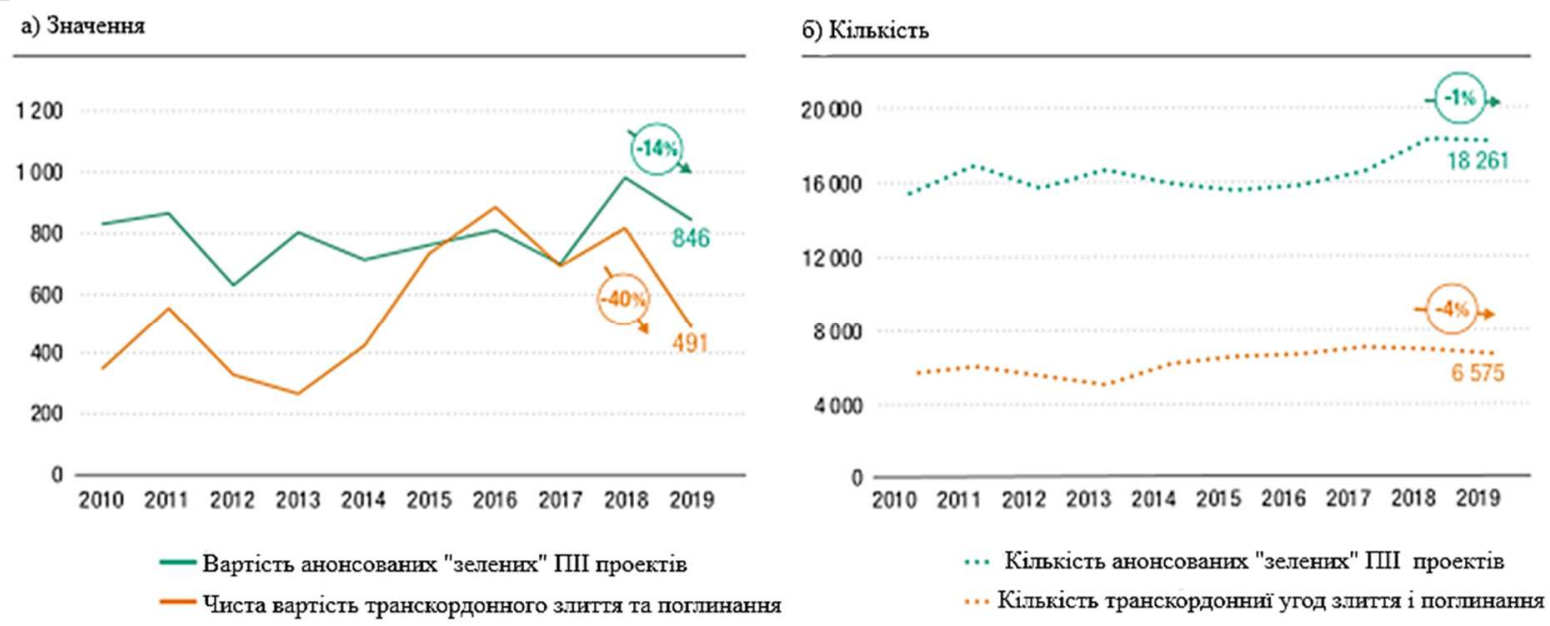

Рис. 5. Вилив пандемї̈ на ПІІ

Джерело: UNCTAD [6].

Криза 2020 року вдарила по більшості галузях. Це на собі відчула українська економіка, особливо - підприємці. Уряд не був готовий до настільки складної ситуації та не зміг захистити бізнес належною фінансовою підтримкою, як це зробили, наприклад, США, виділивши лише на прямі виплати фізичним особам - платникам податків понад 500 млрд USD; а деякі країни, на кшталт Швеції, надали можливість бізнесу не сплачу- 
ГАЛУЗЕВИЙ АСПЕКТ РОЗВИТКУ НАЦІОНАЛЬНОГО ГОСПОДАРСТВА

вати податки на певний період. Так, було виділено одноразову допомогу в розмірі 8000 грн для ФОПів та найманих працівників. Однак, на думку експертів, аналітиків та безпосередньо підприємців, цього недостатньо.

Багато інвестиційних проєктів стали збитковими, через що чимало іноземних інвесторів втратили свої кошти та почали виводити з України інвестиції. Хоча деяким проєктам пандемія коронавірусу дала можливість заявити про себе та стати в нагоді користувачам 3 усього світу. За даними джерела mind.ua, українським стартапам, особливо ITпроєктам, лише в 2020 році вдалося залучити інвестицій на суму 130 млн дол. - підписано 28 публічних угод. А також 14 вливань, сума залучених інвестицій за якими не розголошується [8].

Останніми роками ми маємо світову тенденцію до подолання просторових бар'єрів за допомогою інтернету. Всесвітньовідомий психоаналітик Дж. Сулер пояснює попит на соціальні онлайн-платформи тим, що користувач має можливість знайти собі подібних, виразити себе різними способами, при цьому залишаючись анонімним у разі певної невдачі. Іншими словами - людина має змогу не полишати «зони комфорту» [9]. Опираючись на цю тенденцію, можна зробити припущення щодо популяризації сервісів 3 доставки. Однак експерти не поспішають прогнозувати подальший розвиток цієї сфери. На їх думку, пік припав на минулий 2020-й рік, коли доставка, особливо безконтактна, була інструментом стримування населення всієї планети відвідувати людні місця 3 метою непоширення коронавірусу. За останні декілька років на ринок України зайшли такі «світові гіганти», як Glovo та UberEats. Остання зупинила свою діяльність весною того ж року. Сьогодні українці переважно використовують українську альтернативу - Rocket (ТОВ «РОКЕТ ДЕЛІВЕРІ»). Згадані вище сервіси доставляють будь-що, тоді як українські стартапи Zakaz.ua та Liki24 спеціалізуються на певній категорії товарів (продукти із супермаркетів та ліки). Враховуючи успіх українських компаній, можна підтвердити переваги спеціалізації [10-14].

Стратегічне бачення інвестиційних процесів відповідно до євроінтеграційних зрушень в економіці та з урахуванням венчурних інвестицій зустрічається у роботах Кичко I.I., а саме автор зазначає, що «інвестиційно-інноваційний потенціал взаємодії України та Європейського Союзу залежить від впливу науки і новітніх технологій на посилення конкурентоспроможності в частині експорту кінцевої продукції з високою доданою вартістю, ії місця у міжнародному співтоваристві...» [20-21].

Вільні (спеціальні) економічні зони (ВЕ3 або СЕ3) прийнято вважати частинами території держави, на яких діє пільговий режим оподаткування; фінансові пільги у вигляді субсидій від Уряду, пільгові ставки кредитування; спрощена співпраця з іноземними інституціями; пільговий міграційний режим та особливий правовий режим у сфері регулювання господарської діяльності. Вільні економічні зони створюються з метою притоку іноземних інвестицій, переважно «депресивним регіонам», надання нових робочих місць, співпраці з іноземними інвесторами для розвитку підприємницької діяльності, і як наслідок - виготовлення та поставка якісної продукції на внутрішній ринок. Ініціаторами створення можуть виступати Президент України чи Кабінет Міністрів України, а також місцеві Ради народних депутатів України та місцеві державні адміністрації. Прийняти рішення про створення, строк дії, статус і територію ВЕЗ має Верховна Рада України.

Закон України «Про загальні засади створення функціонування спеціальних (вільних) економічних зон» був прийнятий в 1992 році, однак у 2005 році пільговий режим було скасовано. Причиною стала неефективність дії вільних економічних зон та території пріоритетного розвитку (ТПР) за спеціальним режимом інвестиційної діяльності. За роки свого функціонування спеціальні економічні зони принесли в економіку України 7 млрд дол. замість очікуваних 48. Фактично, з 2005 року фізичні та юридичні особи в 
ВE3 і ТПР здійснюють підприємницьку діяльність відповідно до загальних правил оподаткування без будь-яких преференцій. Експерти переконані, що головними передумовами до скасування пільг були: зловживання підприємствами спеціальним пільговим режимом, що виникли в зв'язку з непрозорим процесом надання пільг та корумпованістю; а також масові порушення митного та податкового законодавств через майже відсутній контроль діяльності ВЕЗ з боку держави.

Вільні економічні зони та території пріоритетного розвитку на момент 1 жовтня 2015 року реалізували лише незначну частину проєктів. 3 десяти ВЕЗ та шістдесяти п'яти ТПР лише дванадцять можна вважати такими, що функціонують. Усього було залучено 972,6 млн дол. інвестицій, 3 яких частка іноземних становить лише 37,9\% $(9,2 \%$ - ПІІ). Найбільше інвестиційних внесків зробили Німеччина та Японія. Унаслідок відсутності конкретних прописаних умов ЗЕД вільна економічна зона на території Луганської та Донецької областей фактично не запрацювала [15].

Одним із видів вільної економічної зони є банківсько-страхова, тобто офшорна. Інформаційні джерела та науковці дають різні визначення стосовно офшорів, але, на нашу думку, вони являють собою здебільшого економічні території країни, де відсутній податок як такий, або ставка є надзвичайно низькою. Також в офшорних зонах відсутня прозорість операцій, що проводяться в межах країни, та обмін інформацією. Зареєстрована в офшорі компанія не має права вести будь-яку діяльність на території країни«податкового притулку».

Офшори мають такі характеристики: низька або нульова ставка на певний вид капіталу або доходу; комерційна та банківська таємниця; відсутність валютного та банківського контролю (що свідчить про те, що можна легко як перерахувати гроші в офшор, так і забрати їх звідти); банківська система є розвинутою; наявність професійних консультантів.

Легальною метою використання офшорів можна вважати оптимізацію податків. Якщо, наприклад, сплатити податок на прибуток з продажу компанії в офшорі в меншому розмірі, і тим самим залучивши в країну резидента більше коштів. Проте, на погляд експертів, навіть якщо оптимізація є правомірною, вона в будь-якому випадку суперечить меті закону. У багатьох офшорах використовують Британське право, яке прийнято вважати одним із найнадійніших у світі. Тобто, продаючи компанію через офшори, власник може бути впевненим, що суд із надуманих підстав не оскаржить угоду. Однак, на жаль, найчастіше офшори використовують у протизаконних та нищівних для української економіки випадках. Ухилення від податку - древній прийом з античними коренями. Багаті мешканці Афін, задля уникнення оплати мита, здійснювали торгівлю поза межами міста. Однією з цілей ведення бізнесу через офшор є приховування кінцевого власника компанії, що допомагає людям с великими статками зберігати в «податкових гаванях» кошти, залишаючись повністю анонімними. Беручи до уваги статистичні дані щодо країн, з яких надходить найбільше прямих іноземних інвестицій, робимо припущення, що власники зареєстрованих в офшорах компаніях можуть працювати за схемою «відмивання грошей». Найпопулярнішою схемою є такий спосіб, коли власник-резидент однієї української компанії укладає договір з іншою своєю компанією, зареєстрованої в офшорі, з приводу купівлі-продажу товарів, яких фактично не існує. Після чого з офшору кошти потрапляють або у вигляді інвестицій до української компанії, або у вигляді рухомого й нерухомого майна.

Економіст Каліфорнійського університету Габріель Цукман припускає, що в офшоpax знаходиться близько 10 \% світового ВВП. Зокрема, від 2-3 \% ВВП у Скандинавії, до 15 \% в Свропі. У країнах Латинської Америки та Перської затоки цей показник може 
ГАЛУЗЕВИЙ АСПЕКТ РОЗВИТКУ НАЦІОНАЛЬНОГО ГОСПОДАРСТВА

перевищувати 60 \% від валового внутрішнього продукту. У 2016 р. розгорівся «гучний» світовий скандал, коли з панамської фірми, що спеціалізувалась на реєстрації та супроводі офшор, Mossack Fonseca було викрадено 11,5 млн документів. Після їх оприлюднення стали відомі списки клієнтів компанії, серед яких політики та інші публічні діячі, які є співвласниками 240 компаній з 200 країн світу.

За Розпорядженням Кабінету Міністрів від 23 лютого 2011 року № 143-р «Про перелік офшорних зон», до офшорних зон належить 41 країна та території. Україна протистоїть співпраці компаній-резидентів 3 офшорами 3 допомого реалізації плану BEPS, який був затверджений «великою двадцяткою». План складається 315 етапів, що спрямовані на ліквідацію ухилення від податків та ненадання звітів усіма резидентами, яким підконтрольні зареєстровані за кордоном компанії.

Висновки та пропозиції. Проаналізувавши тенденцію залучення Україною прямих іноземних інвестицій, можна підвести підсумок, що є можливості покращити інвестиційний клімат нашої держави, оскільки потенціал використовується не на повну. Уряду варто налагоджувати інвестиційний клімат насамперед інвестиціями в людський капітал українців. Україна й досі залишається індустріальною країною (експортуємо переважно сировину, а готова високотехнологічна продукція займає лиш низькій відсоток на вітчизняному ринку). Саме постіндустріалізація має стати нашим пріоритетом як інвестиційно привабливого регіону. Наприклад, Японія має обмежену кількість природних ресурсів, однак за рахунок високого рівня якості освіти та розвитку інноваційних технологій її ВВП на душу населення значно вищий, ніж в Україні (49 188 USD проти 3225 USD). Держава просто імпортує ресурси інших країн, а експортує вже готовий, переважно, високотехнологічний продукт за значно вищою ціною, аніж витратила на необхідні ресурси. Україна також має всі шанси стати «інноваційним гігантом». Для цього необхідно притримуватись двох принципів, а саме: прагнення стримати «відтік мізків» 3 України, а також заохочування до створення інноваційних винаходів та проєктів. Стосовно запровадження вільної економічної зони на Донбасі, то для вдалого функціонування BE3 не достатньо буде чітко виписати усі засади - потрібно працювати над роботою судової системи, аби та стала гарантом захисту прав інвестора.

Таким чином, економіка України незадовільним рівнем розвитку і потребує додаткових капіталовкладень у формі притоку іноземних інвестицій для стабілізації та збалансування економічного стану. Проведені реформи в економічній сфері не завжди ефективні й поступова інтеграція вимагає від держави впровадження ефективної інвестиційної політики.

\section{Список використаних джерел}

1. Хелецька А. А. Наукові підходи до визначення механізму регулювання інвестиційної діяльності. Ефективна економіка. 2012. № 2. URL: http://nbuv.gov.ua/UJRN/efek_2012_2_29.

2. Індекси. Прямі іноземні інвестиції в Україні / Міністерство фінансів України. URL: https://index.minfin.com.ua/economy/fdi/2020.

3. Умови ведення ведення бізнесу. Україна. Dooingbusiness.org. URL: https://russian.doingbusiness.org/ru/data/exploreeconomies/ukraine.

4. Удосконалення ведення статистики прямих іноземних інвестицій / Національний банк України. URL: https://bank.gov.ua/ua/file/download?file=FDI_pr_2020-06-26.pdf.

5. Центр Разумкова. Хто і як інвестує в Україну. URL: https://razumkov.org.ua/statti/khto-i-iakinvestuie-v-ukrainu/

6. UNCTAD (preliminary estimates). URL: https://unctad.org/news/global-foreign-directinvestment-fell-42-2020-outlook-remains-weak.

7. World investment report 2020. URL: https://unctad.org/system/files/officialdocument/wir2020_en.pdf. 
8. Mind. Рейтинг українських стартапів - 2020: кому вдалося здобути найбільштй обсяг інвестицій i яким проєктам підвишити оборот допомогла саме пандемія. URL: https://mind.ua/publications/20219740-rejting-ukrayinskih-startapiv-2020-komu-vdalosya-zdobutinajbilshij-obsyag-investicij.

9. John R. Suler. Psychology of the Digital Age: Humans Become Electric. Cambrige U Press. 2016.

10. Раманова Ю.С. Герасимчук В.Г. Механізм підвищення ефективності залучення прямих іноземних інвестицій в економіку України. Економічний вісник НТУУ «КПI». 2017. № 14. C. 417-422.

11. Маркевич К. Л. Регулювання ПІІ в контексті національної безпеки: міжнародний досвід та висновки для України. Теоретичні і прикладні питання економіки : збірник наукових праць. 2020. № 1 (40), C. 141-153.

12. Манзюк О.О. Негативні наслідки діяльності офшорних зон та шляхи їх подолання в Україні. Свропейський вектор економічного розвитку. 2013. № 2(15). С. 172-178.

13. Gabriel Zucman. The Hidden Wealth of Nations one. A Century of Offshore Finance. University of Chicago Press. 2015. 200 p.

14. International Consortium of Investatigative Journalists. The Panama Papers. Exposing the Rogue Offshore Finance Industry. URL: https://www.icij.org/investigations/panama-papers/

15. Вільна економічна зона на Донбасі: чорна діра бюджету. URL: https://www.dw.com/uk/вільна-економічна-зона-на-донбасі-чорна-діра-бюджету/а-55322071

16. Чуницька I. I. Інвестиційний клімат України: сутність, проблеми та шляхи їх вирішення. Приазовський економічний вісник. 2019. Вип. 3(14). С. 111-117.

17. Хоменко І. О., Волинець Л. М., Чубикіна А. О. Стратегічні засади інвестування в людський капітал для забезпечення розвитку національної економіки України. Проблеми $i$ перспективи економіки та управління. 2020. № 1 (21). С. 38-45.

18. Хоменко I.O. Інвестиційне забезпечення відтворення основних фондів. Вісник Чернігівського державного технологічного університету : зб. наук. праць. 2009. № 35. С. 115-119.

19. Хоменко I. О., Каштальян О. О. Особливості становлення, впровадження та розвитку стартапів. Юність науки - 2020: соиіально-економічні та гуманітарні аспекти розвитку суспільства : збірник тез Міжнародної науково-практичної конференції студентів, аспірантів і молодих вчених (м. Чернігів, 23-24 квітня 2020 р.). Чернігів : ЧНТУ, 2020. С. 39-41.

20. Кичко І. І., Савченко В. Ф. Стратегічні орієнтири інвестиційно-інноваційного розвитку в Україні. Здобутки $і$ проблеми євроінтеграчійних зручень в Україні на сучасному етапі: монографія / за заг. ред. В. Ф. Савченка, Л. М. Мекшун. Чернігів : ЧНТУ, 2018. С. 8-29.

21. Кичко I. І. Перспективи реалізації моделі венчурного інвестування в Україні. Проблеми $i$ перспективи економіки та управління. 2016. № 3(7). С. 171-177.

\section{References}

1. Kheletska, A. A. (2012). Naukovi pidkhody do vyznachennia mekhanizmu rehuliuvannia investytsiinoi diialnosti [Scientific approaches to determining the mechanism of regulation of investment activity]. Efektyvna ekonomika - Efficient economy, (2). http://nbuv.gov.ua/UJRN/efek_2012_2_29.

2. Ministerstvo finansiv Ukrainy [Ministry of Finance]. (2020). Indeksy. Priami inozemni investytsii v Ukraini [Indices. Foreign direct investment in Ukraine]. https://index.minfin.com.ua/ economy/fdi/2020.

3. Umovy vedennia vedennia biznesu. Ukraina [Terms of doing business. Ukraine]. (n.d.). Dooingbusiness.org. URL: https://russian.doingbusiness.org/ru/data/exploreeconomies/ukraine/

4. Natsionalnyi bank Ukrainy [National Bank of Ukraine]. (2020). Udoskonalennia vedennia statystyky priamykh inozemnykh investytsii [Improving foreign direct investment statistics]. https://bank.gov.ua/ua/file/download?file=FDI_pr_2020-06-26.pdf/

5. Tsentr Razumkova. Khto i yak investuie v Ukrainu [Razumkov Center. Who and how invests in Ukraine]. https://razumkov.org.ua/statti/khto-i-iak-investuie-v-ukrainu.

6. UNCTAD (preliminary estimates). https:/unctad.org/news/global-foreign-direct-investmentfell-42-2020-outlook-remains-weak. 
ГАЛУЗЕВИЙ АСПЕКТ РОЗВИТКУ НАЦІОНАЛЬНОГО ГОСПОДАРСТВА

7. World investment report 2020. (2020). https://unctad.org/system/files/official-document/ wir2020_en.pdf.

8. Mind. Reitynh ukrainskykh startapiv - 2020: komu vdalosia zdobuty naibilshti obsiah investytsii i yakym proiektam pidvyshyty oborot dopomohla same pandemiia [Mind. Rating of Ukrainian startups - 2020: who managed to get the largest amount of investment and which projects to increase turnover helped the pandemic]. (n.d.). URL: https://mind.ua/publications/20219740-rejtingukrayinskih-startapiv-2020-komu-vdalosya-zdobuti-najbilshij-obsyag-investicij.

9. John R. Suler. (2016). Psychology of the Digital Age: Humans Become Electric. Cambrige U Press.

10. Ramanova, Yu. S. (2017). Mekhanizm pidvyshchennia efektyvnosti zaluchennia priamykh inozemnykh investytsii $\mathrm{v}$ ekonomiku Ukrainy [Mechanism for increasing the attraction of foreign direct investment in the economy of Ukraine]. Ekonomichnyi visnyk NTUU «KPI»-Economic Bulletin of NTUU "KPI", (14), pp. 417-422.

11. Markevich, K. L. (2021). Rehuliuvannia PII v konteksti natsionalnoi bezpeky: mizhnarodnyi dosvid ta vysnovky dlia Ukrainy [Realization of national economic interests of Ukraine in attracting foreign direct investment]. Teoretychni i prykladni pytannia ekonomiky - Theoretical and applied issues of economics, (1(40)), pp. 141-153.

12. Mandzyuk, O.O. (2013). Nehatyvni naslidky diialnosti ofshornykh zon ta shliakhy yikh podolannia $\mathrm{v}$ Ukraini [Negative consequences of offshore zones and ways to overcome them in Ukraine]. Yevropeiskyi vektor ekonomichnoho rozvytku - European vector of economic development, (2(15)), pp. 172-178.

13. Gabriel Zucman. (2015). UC Berkeley. The Hidden Wealth of Nations.

14. International Consortium of Investatigative Journalists. The Panama Papers. Exposing the Rogue Offshore Finance Industry. https://www.icij.org/investigations/panama-papers.

15. DW. Free economic zone in Donbass: a black hole in the budget. https://www.dw.com/uk/вільна-економічна-зона-на-донбасі-чорна-діра-бюджету/a-55322071.

16. Chunytska, I. I. (2019). Investytsiinyi klimat Ukrainy: sutnist, problemy ta shliakhy yikh vyrishennia [Investment climate of Ukraine: essence, problems and ways of their solution]. Pryazovskyi ekonomichnyi visnyk - Priazovsky Economic Bulletin, (3(14)), pp. 111-117.

17. Khomenko I. O., Volynets L. M., Chubykina A. O. (2020). Stratehichni zasady investuvannia v liudskyi kapital dlia zabezpechennia rozvytku natsionalnoi ekonomiky Ukrainy [Strategic principles of investing in human capital to ensure the development of the national economy of Ukraine]. Problems and prospects of economics and management - Problemy i perspektyvy ekonomiky ta upravlinnia, (1(21)), pp. 38-45.

18. Khomenko, I. O. (2009). Investytsiine zabezpechennia vidtvorennia osnovnykh fondiv [Investment support for the reproduction of fixed assets]. Visnyk Chernihivskoho derzhavnoho tekhnolohichnoho universytetu - Bulletin of Chernihiv State Technological University, (35), pp. 115-119.

19. Khomenko, I. O., Kashtalian, O. O. (2020). Osoblyvosti stanovlennia, vprovadzhennia ta rozvytku startapiv [Features of formation, implementation and development of startups]. In Yunist nauky - 2020: sotsialno-ekonomichni ta humanitarni aspekty rozvytku suspilstva - Youth of Science 2020: socio-economic and humanitarian aspects of society development (pp. 39-41). ChSTU.

20. Kychko, I. I., Savchenko, V. F. (2018). Stratehichni oriientyry investytsiino-innovatsiinoho rozvytku v Ukraini [Strategic guidelines for investment and innovation development in Ukraine]. In V. F. Savchenko, L. M. Mekshun (Eds.), Zdobutky i problemy yevrointehratsiinykh zrushen $v$ Ukraini na suchasnomu etapi - Achievements and problems of European integration changes in Ukraine at the present stage (pp.8-29). ChNTU.

21. Kychko, I. I. (2016). Perspektyvy realizatsii modeli venchurnoho investuvannia v Ukraini [Prospects for the implementation of the venture investment model in Ukraine]. Problemy $i$ perspektyvy ekonomiky ta upravlinnia - Problems and prospects of economics and management, (3(7)), pp. 171-177. 
ГАЛУЗЕВИЙ АСПЕКТ РОЗВИТКУ НАЦІОНАЛЬНОГО ГОСПОДАРСТВА

|Хоменко Інна Олександрівна - доктор економічних наук, професор, професор кафедри теоретичної та прикладної економіки, Національний університет «Чернігівська політехніка» (вул. Шевченка, 95, м. Чернігів, 14035, Україна).

Khomenko Inna - Doctor of Economics, professor, professor of the Department of Theoretical and Applied Economics, Chernihiv Polytechnic National University (95 Shevchenko Str., 14035 Chernihiv, Ukraine).

E-mail: innakhomenko28@gmail.com

ORCID: https://orcid.org/0000-0002-0839-4636

ResearcherID: F-3881-2014

Волинець Людмила Миколаївна - кандидат економічних наук, доцент, доцент кафедри транспортного права та логістики, Національний транспортний університет (вул. Омеляновича-Павленко, 1, м. Київ, 01010, Україна).

Volynets Lyudmila - PhD in Economics, associate professor, associate professor of the Department of Transport

Law and Logistics, National Transport University (1 Omelyanovicha-Pavlenko Str., 01010 Kyiv, Ukraine).

E-mail: Volinec 3@ukr.net

ORCID: https://orcid.org/0000-0002-5064-2349

Шамкало Антон Олегович - молодший спеціаліст, Національний університет «Чернігівська політехніка» (вул. Шевченка, 95, Чернігів, 14027, Україна).

Shamkalo Anton - Junior Specialist, Chernihiv Polytechnic National University (Shevchenko str., 95, Chernihiv, 14027, Ukraine).

E-mail: ashamkalo2110@gmail.com

Хоменко І., Волинець Л., Шамкало А. Особливості надходження прямих іноземних інвестицій та їхній вплив на економіку України. Проблеми і перспективи економіки та управління. 2021. № 1(25). С. 15-26. 